\title{
PENGARUH STRUKTUR ORGANISASI, KEPEMIMPINAN DAN KOMPETENSI PEGAWAI TERHADAP EFEKTIVITAS PELAYANAN PROGRAM ONE DAY SER VICE DI KANTOR PERTANAHAN KOTA MATARAM
}

\author{
Lalu Parjadinata ${ }^{1}$, Surati $^{2}$, Dwi Putra Buana Sakti ${ }^{3}$ \\ ${ }^{1}$ Faculty of Economics and Business, University of Mataram. \\ Email: laluparjadinata@gmail.com \\ 2,3Faculty of Economics and Business, University of Mataram.
}

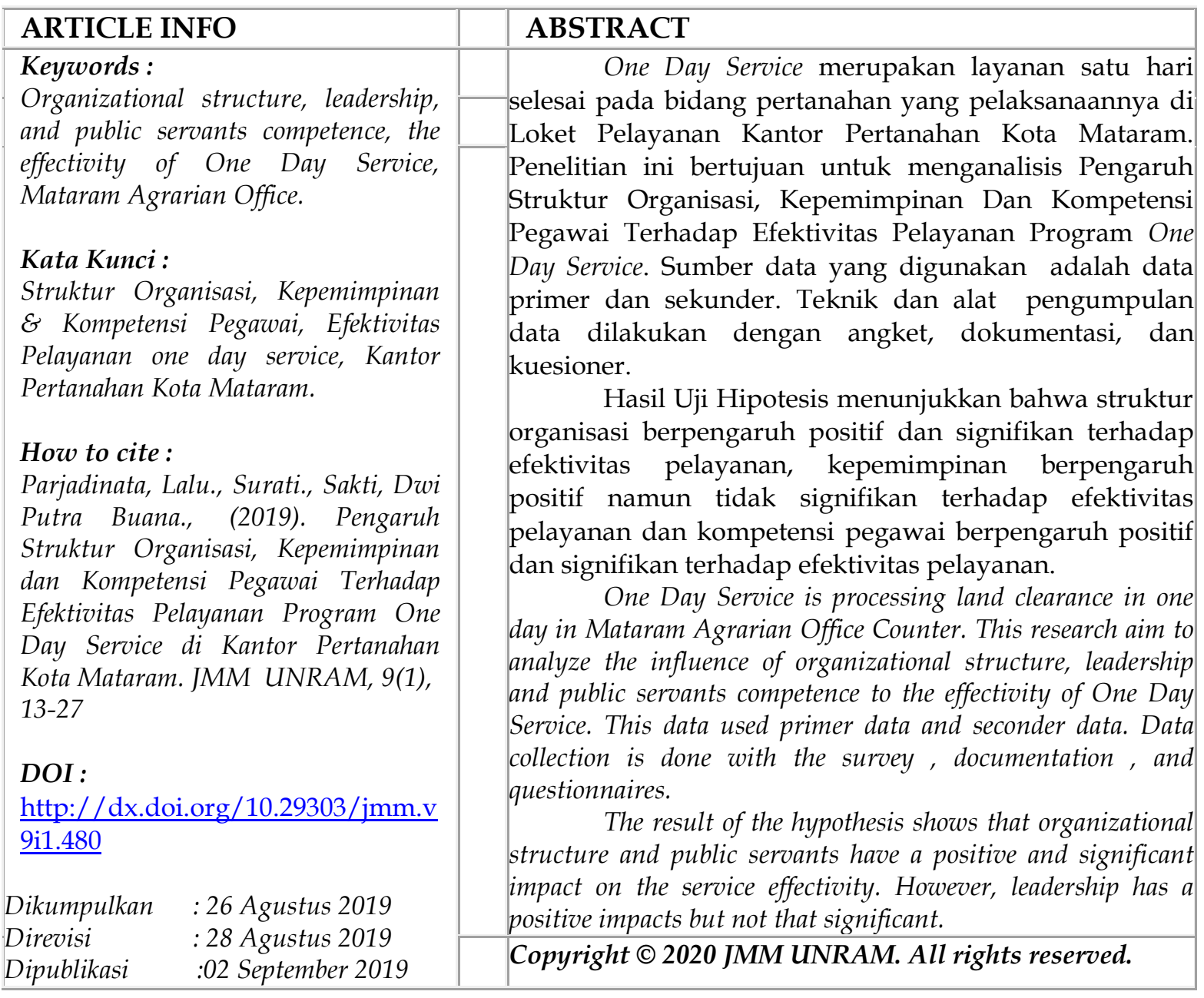




\section{PENDAHULUAN}

Pada era globalisasi saat ini, perkembangan dan kemajuan dalam berbagai bidang selalu mengedepankan efektivitas kerja para pegawai untuk menjalankan suatu organisasi. Terciptanya efektivitas kerja yang baik diharapkan mampu untuk dapat menjamin percepatan, kelancaran, pelayanan terhadap masyarakat secara baik dan tepat. Efektivitas pada dasarnya menunjukkan pada taraf tercapainya hasil, sering atau senantiasa dikaitkan dengan pengertian efisien, meskipun sebenarnya ada perbedaan diantara keduanya.

Efektivitas kerja merupakan suatu tingkatan keberhasilan yang dicapai seseorang dengan melakukan tugas-tugas yang dibebankan kepadanya yang didasarkan pada kecakapan, pengetahuan dan kesungguhan serta waktu. Efektivitas kerja yang baik akan datang apabila pekerja mengerti akan arahan-arahan yang diberikan oleh pimpinan, dalam hal ini efektifitas kerja adalah penyelesaian pekerjaan tepat pada waktu yang sudah ditetapkan artinya pelaksanaan suatu pekerjaan dinilai baik atau tidak bergantung pada penyelesaian pekerjaan tersebut, bagaimana melaksanakan dan biaya yang dikeluarkan untuk itu (Siagian 2002 : 67).

Pelayanan publik merupakan hal yang penting untuk mencapai tujuan dan sasaran di dalam setiap organisasi dan instansi.Salah satu lembaga Pemerintahan yang melakukan pelayanan publik adalah Kementerian Agraria dan Tata Ruang.Untuk mewujudkan pelayanan yang prima kepada masyarakat. BPN RI telah melakukan inovasi-inovasi pelayanan pertanahan. Berbagai inovasi telah dilaksanakan baik oleh BPN Pusat, Kantor Wilayah BPN Provinsi maupun Kantor Wilayah Pertanahan Kabupaten/Kota yang tersebar di seluruh pelosok negeri. Inovasi tersebut salah satunya adalahLayanan Satu Hari Selesai (One Day Service).

Indikator dari berhasilnya efektivitas kerja adalah, apabila struktur organisasi berjalan secara efektif. Struktur organisasi menjadi hal yang tidak bisa dipisahkan dari organisasi. Struktur organisasi memberikan gambaran bagi yang ingin mengenal atau sekedar ingin mengetahui tentang organisasi yang bersangkutan. Struktur organisasi menjadi salah satu strategi organisasi dalam mencapai tujuan, karena tergambar jelas tentang tugas, fungsi, garis wewenang, tanggung jawab, pola formal kegiatan dan hubungan antar sub unit dalam organisasi untuk mencapai tujuan organisasi itu sendiri.

Keberhasilan suatu organisasi dalam mencapai tujuan tidaklah bisa dilepaskan dari kualitas pemimpinnya. Kepemimpinan merupakan faktor yang menentukan dalam suatu organisasi. Berhasil atau gagal organisasi dalam mencapai suatu tujuan dipengaruhi oleh cara seorang pemimpin. Sosok pemimpin tersebut mampu mengelola organisasi secara efektif apabila pemimpin tersebut mampu mempengaruhi prilaku bawahan agar bekerja sama dalam mencapai tujuan.

Keberhasilan suatu program layanan publik juga tidak terlepas dari sumber daya manusia dan kompetensi pegawai sebagai eksekutor program. Spencer dalam Wibowo (2013:325-326) menyatakan bahwa kompetensi merupakan landasan dasar karakteristik orang dan mengindikasikan cara berperilaku atau berfikir, menyamakan situasi, dan mendukung untuk periode waktu cukup lama.Mengelola sumber daya manusia berdasarkan kompetensi diyakini bisa lebih menjamin keberhasilan mencapai tujuan. Sebagian besar perusahaan memakai kompetensi sebagai dasar dalam memilih orang, mengelola kinerja, pelatihan dan pengembangan serta pemberian kompensasi.

Penelitian ini terfokus pada efektivitas pelayanan program one day service. Bentuk layanan One Day Service ini merupakan layanan satu hari selesai di bidang pertanahan yang dilaksanakan pada Loket Pelayanan Kantor Pertanahan. Tujuan dilaksanakannya One Day Service adalah untuk mempermudah pelayanan di bidang pertanahan, mempersingkat 
alur birokrasi pelayanan di bidang pertanahan, mewujudkan harapan masyarakat pengguna layanan di bidang pertanahan serta mewujudkan komitmen BPN RI memberikan pelayanan yang cepat dan cermat. Selain itu dengan upaya ini diharapkan mampu memangkas peran para calo yang menyebabkan "biaya tinggi" dalam pengurusan layanan pertanahan.

One Day Service dilaksanakan untuk beberapa jenis layanan pertanahan tertentu. Jenis layanan pertanahan dalam One Day Service disetiap Kantor Pertanahan dilaksanakan berdasarkan ketersediaan data pertanahan, sumber daya manusia serta infrastruktur teknologi informasi dan komunikasi yang tersedia. Beberapa layanan pertanahan dalam program One Day Service yaitu : a), Pengecekan Sertipikat, b), Penghapusan Hak Tanggungan (Roya), c), Pendaftaran Hak Milik Berdasarkan Surat Keputusan, d) Peningkatan Hak / Perubahan Hak, d) Peralihan Hak, e) Surat Keterangan Pendaftaran Tanah (SKPT), f) Perpanjangan Hak Tanpa Ganti Blanko, g) Pencatatan Sita dan h) Pencatatan Blokir.

Berdasarkan hasil observasi dan wawancara langsung dengan Kepala Kantor Pertanahan terhadap fenomena di Kantor Pertanahan Kota Mataram, didapatkan sebagian pegawai menunjukan perilaku-perilaku seperti lambatnya pegawai dalam bekerja, rendahnya prestasi,rendahnya kinerja dan masalah disiplin pegawai yang mencerminkan kurangnya efektivitas pelayanan one day service kepada masyarakat. Kurangnya pegawai yang memiliki kemampuan dalam teknologi menyebabkan sering terlambatnya dalam pelayanan one day service. Sedangkan kalau ditinjau dari pembagian tugas-tugas diakuinya masih banyak terdapat penempatan pegawai tidak sesuai dengan kemampuan yang mereka miliki disebabkan karena kekurangan jumlah pegawai. Kondisi di atas mengindikasikan adanya permasalahan terkait efektivitas pelayanandi Kantor Pertanahan Kota Mataram.

Data awal untuk memperkuat kurang efektifnya pelayanan program "One Day Service" di BPN Kota Mataram dapat dilihat dari angka kepuasan masyarakat selama tiga tahun terakhir mulai Tahun 2016 s/d 2018 berdasarkan tabel di bawah ini :

Tabel : Porsentase Indek Kepuasan Masyarakat terhadap Pelayanan Program One Day ServiceTahun 2016 sd 2018

\begin{tabular}{|l|c|c|c|}
\hline \multirow{2}{*}{ Kriteria } & \multicolumn{3}{|c|}{ Tahun } \\
\cline { 2 - 4 } & 2016 & 2017 & 2018 \\
\hline Sangat Puas & $72,7 \%$ & $80 \%$ & $59 \%$ \\
\hline Puas & $25,5 \%$ & $18 \%$ & $36 \%$ \\
\hline Tidak Puas & $1,8 \%$ & $2 \%$ & $5 \%$ \\
\hline Jumlah & $\mathbf{1 0 0} \%$ & $\mathbf{1 0 0} \%$ & $\mathbf{1 0 0} \%$ \\
\hline
\end{tabular}

Sumber : BPN Kota Mataram Tahun 2019

Berdasarkan data Indek Kepuasan Masyarakat tiga tahun terakhir, porsentase indek kepuasan pelayanan Program One Day Service masih fluktuatif. Pada tahun 2016 tercatat : kriteria Sangat puas $=72,7 \%$, Puas $=25,5 \%$, Tidak Puas $=1,8 \%$. Pada tahun 2017 tercatat : kriteria Sangat puas $=80 \%$, Puas $=18 \%$, Tidak Puas $=2 \%$. Sedangkan pada tahun 2018 porsentase jauh menurun dari data dua tahun sebelumnya dengan presentase sebagai berikut : Sangat puas $=59 \%$, Puas $=36 \%$, Tidak Puas $=5 \%$.

Meningkatnya persentase kriteria tidak puas dalam IKM pada tahun 2018 disebabkan karena seringnya pimpinan tidak berada di kantor yang bertepatan dengan jadwal pelayanan One Day Service sehingga dalam proses penandatanganan berkas menjadi terlambat. Faktor lain juga disebabkan karena minimnya jumlah pegawai yang memiliki kemampuan di bidang teknologi, dari informasi yang peneliti dapatkan, Kantor 
Pertanahan Kota Mataram hanya memiliki 1 orang pegawai yang mengerti masalah IT. Ketika terjadi kendala terhadap system sering kali pegawai tersebut lambat dalam menanganinya sehingga menyebabkan pelayanan One Day Service tertunda.

Berdasarkan permasalahan dan latar belakang di atas maka peneliti tertarik untuk melakukan penelitian tentang pengaruh struktur organisasi, kepemimpinan, dan kompetensi pegawai terhadap efektivitas pelayanan program "One Day Service"diKantor Pertanahan Kota Mataram.

\section{TUJUAN PENELITIAN}

Berdasarkan perumusan masalah yang ada, maka tujuan penelitian ini sebagai berikut :

1) Untuk mengetahui pengaruh struktur organisasi terhadap efektivitas pelayanan program "one day service" di kantor pertanahan Kota Mataram.

2) Untuk mengetahui pengaruh kepemimpinan terhadap efektivitas pelayanan program "one day service" di kantor pertanahan Kota Mataram.

3) Untuk mengetahui pengaruh kompetensi pegawai terhadap efektivitas pelayanan program "one day service" di kantor pertanahan Kota Mataram.

\section{LANDASAN TEORI}

\subsection{Efektivitas Pelayanan}

Orientasi dalam penelitian tentang efektivitas sebagian besar dan sedikit banyaknya pada akhirnya bertumpu pada pencapaian tujuan. George poulus Tenenbaum (Richard M. Steers, 1985 : 20) berpendapat bahwa konsep efektivitas kadang-kadang disebut sebagai keberhasilan yang biasanya digunakan untuk menunjukan pencapaian tujuan. Chester I. Barnard (dalam Gibson, 1994 : 27), mendefinisikan efektivitas sebagai pencapaian sasaran yang telah disepakati atas usaha bersama. Tingkat pencapaian sasaran itu menunjukan tingkat efektivitas.

Efektivitas merupakan penyelesaian pekerjaan tidak hanya dipandang dari segi pencapaian tujuan saja tetapi juga dari segi ketepatan waktu dalam mencapai tujuan tersebut. Dari pendapat diatas disimpulkan bahwa efektivitas berkaitan dengan masalah waktu. Suatu kegiatan dikatakan efektif apabila kegiatan tersebut berhasil diselesaikan sesuai dengan waktu yang telah ditetapkan atau dalam kata lain tepat waktu (Siagian 2003:27).

Moenir (2001:vii) mengatakan bahwa pelayanan adalah kunci keberhasilan dalam berbagai usaha atau kegiatan yang bersifat jasa. Jadi dalam memberikan pelayanan yang efektif dapat berarti tercapainya tujuan pelayanan yang telah ditetapkan organisasi dan masyarakat merasa puas dengan pelayanan yang didapatnya.

Konsep tentang pelayanan publik yang telah diuraikan di atas, bahwa pelayanan publik adalah suatu usaha yang dilakukan oleh seseorang atau kelompok orang atau instansi tertentu untuk memberikan bantuan dan kemudahan kepada masyarakat atau kelompok yang dilayani dalam rangka mencapai tujuan tertentu. Maka, dapat dikatakan bahwa efektivitas pelayanan adalah tercapainya suatu tujuan yang dilakukan oleh pemberi layanan sesuai dengan ketentuan yang telah ditetapkan.

Berdasarkan Keputusan Menteri Pendayagunaan Aparatur Negara No. 63 Tahun 2004 (Ratminto, 2005:177) tentang pedoman umum penyelenggaraan pelayanan publik, standar pelayanan publik sekurang-kurangnya meliputi : 
1) Prosedur Pelayanan : Prosedur pelayanan yang dibakukan bagi pemberi dan penerima pelayanan termasuk pengaduan.

2) Waktu Penyelesaian : Waktu penyelesaian yang ditetapkan sejak saat pengajuan permohonan sampai dengan penyelesaian termasuk pengaduan.

3) Biaya Pelayanan : Biaya/ tarif pelayanan termasuk rinciannya yang ditetapkan dalam proses pemberian layanan.

4) Produk Pelayanan : Hasil pelayanan yang akan diterima sesuai dengan ketentuan yang telah ditetapkan.

5) Sarana dan Prasarana : Penyediaan sarana dan prasarana pelayanan yang memadai oleh penyelenggaraan pelayanan publik.

6) Kompetensi Petugas Pemberi Pelayanan Publik : Kompetensi petugas pemberi pelayanan harus ditetapkan dengan tepat sesuai berdasarkan pengetahuan, keahlian, keterampilan, sikap dan prilaku yang dibutuhkan.

\subsection{Struktur Organisasi}

Setiap Organisasi pada umumnya mempunyai struktur organisasi. Penyusunan struktur organisasi merupakan langkah awal dalam memulai pelaksanaan kegiatan organisasi, dengan kata lain penyusunan struktur organisasi adalah langkah terencana dalam suatu perusahaan untuk melaksanakan fungsi perencanaan, pengorganisasian, pengarahan, dan pengawasan. Struktur organisasi menjelaskan bagaimana tugas kerja akan dibagi, dikelompokkan dan dikoordinasikan secara formal. Struktur organisasi menunjukkan kerangka dan susunan perwujudan pola tetap hubungan diantara fungsi, bagian atau posisi maupun orang-orang yang menunjukkan tugas, wewenang dan tanggung jawab yang berbeda-beda dalam suatu organisasi. Kerangka kerja organisasi tersebut disebut sebagai desain organisasi (organizational design) dan bentuk spesifik dari kerangka kerja organisasi dinamakan dengan struktur organisasi (organizational structure).

Gibson dkk (1989:16 dan 17) bahwa struktur organisasi bukan hanya susunan porsi, tugas-tugas pekerjaan dan garis wewenang dari bagian-bagian dalam organisasi, tetapi merupakan pola formal kegiatan dan hubungan di antara berbagai subunit dalam organisasi. Struktur organisasi menjelaskan tentang pembagian tugas dan wewenang, tetapi struktur organisasi juga menjelaskan bagaimana pola hubungan kerja dari setiap unit yang ada.

Handoko dalam Ambonowati (2002: 23) menyebutkan bahwa struktur organisasi dapat didefinisikan sebagai mekanisme-mekanisme formal dengan mana organisasi dikelola. Handoko juga menyebutkan bahwa struktur organisasi ini mengadung unsurunsur spesialisasi kerja, standarisasi, koordinasi, sentralisasi atau desentralisasi dalam pembuatan keputusan dan besaran (ukuran) satuan kerja.

Menurut Hasibuan (2011:128) definisi struktur organisasi adalah sebagai berikut : "Suatu gambar yang menggambarkan tipe organisasi, pendepartemenan organisasi kedudukan dan jenis wewenang pejabat, bidang dan hubungan pekerjaan, garis perintah dan tanggung jawab, rentang kendali dan sistem pimpinan organisasi."

Adapun penjelasan struktur organisasi lainnya yang masih berkaitan dengan penjelasan diatas bahwa "dari merancang struktur organisasi para pemimpin organisasi mampu menentukan harapan-harapan mengenai apa yang akan dilakukan individu individu dan kelompok - kelompok tersebut dalam mencapai tujuan-tujuan organisasi" (Ivancevich, 2007:235). Jika struktur organisasi merupakan media yang membantu organisasi dalam mencapai tujuan-tujuannya, maka "efektivitas organisasi didefinisikan sebagai sejauh mana sebuah organisasi mewujudkan tujuan-tujuannya" (Robbins, 1994:53). 


\subsection{Kepemimpinan}

Kepemimpinan adalah merupakan proses pemimpin yang mempengaruhi pengikut untuk menginterpretasikan keadaan, pemilihan tujuan organisasi, pengorganisasian kerja dan memotivasi pengikut untuk mencapai tujuan organisasi, mempertahankan kerjasama dan tim kerja, mengorganisir dukungan dan kerja sama orang dari luar organisasi. (Yukl dalam Idris, 2006 : 57).

Pemimpin (Leader) pada dasarnya adalah orang yang mampu menggerakkan sumberdaya (terutama manusia) untuk bekerja bersama untuk mencapai tujuan. Menurut Jack Welch dalam Slater (2001 : 33), pemimpin adalah orang yang memberikan inspirasi dengan visi yang jelas mengenai bagaimana sesuatu dapat dikerjakan dengan cara yang lebih baik.

Pemimpin dan kepemimpinan adalah sesuatu yang tak dapat dipisahkan, merupakan suatu kesatuan. Seorang pemimpin harus mempunyai jiwa kepemimpinan. Jiwa kepemimpinan ini terbentuk dari suatu proses dari waktu ke waktu hingga akhirnya akan mengkristal dalam suatu bentuk karakteristik kepemimpinan. Seseorang yang mempunyai jiwa kepemimpinan, dengan usaha yang gigih akan dapat membantu lahirnya penegasan sikap kepemimpinan pada dirinya (Fahmi, $2012: 16$ ).

Robbins (2003 : 40) menyatakan bahwa kepemimpinan (leadership) adalah kemampuan untuk mempengaruhi suatu kelompok kearah tercapainya tujuan. Sementara Stoner (1996 : 161) menyatakan bahwa kepemimpinan adalah proses mengarahkan dan mempengaruhi aktifitas yang berkaitan dengan pekerjaan dari anggota kelompok.

Kepemimpinan merupakan kemampuan seseorang untuk mempengaruhi suatu kelompok kearah tercapainya tujuan. Menurut Siagian (2002) mengemukakan bahwa kepemimpinan adalah kemampuan seseorang untuk mempengaruhi orang lain (para bawahannya) sedemikian rupa sehingga orang lain itu mau melakukan kehendak pemimpin meskipun secara pribadi hal itu mungkin tidak disenanginya.

Anoraga et al. (1995) dalam Tika (2006 : 64) mengemukakan bahwa ada sembilan peranan kepemimpinan seorang dalam organisasi yaitu pemimpin sebagai perencana, pemimpin sebagai pembuat kebijakan, pemimpin sebagai ahli, pemimpin sebagai pelaksana, pemimpin sebagai pengendali, pemimpin sebagai pemberi hadiah atau hukuman, pemimpin sebagai teladan dan lambang atau simbol, pemimpin sebagai tempat menimpakan segala kesalahan, dan pemimpin sebagai pengganti peran anggota lain.

Fungsi pemimpin didalam organisasi menurut Terry (1960) dialih bahasakan oleh Sutrisno (2010 : 219) dapat dikelompokkan menjadi empat, yaitu : perencanaan, penggerakan, pengorganisasian, dan pengendalian. Dalam menjalankan fungsinya pemimpin mempunyai tugas - tugas tertentu, yaitu mengusahakan agar kelompoknya dapat mencapai tujuan dengan baik dalam bekerja sama yang optimal.

\subsection{Kompetensi Pegawai}

Kompetensi menurut Wibowo (2010: 324) adalah suatu kemampuan untuk melaksanakan atau melakukan suatu perkerjaan atau tugas yang dilandasi atas keterampilan dan pengetahuan serta didukung oleh sikap kerja yang dituntut oleh pekerjaan tersebut. Dengan demikian, kompetensi menunjukkan keterampilan atau pengetahuan yang dicirikan oleh profesionalisme dalam suatu bidang tertentu sebagai sesuatu yang terpenting, sebagai unggulan bidang tersebut.

Menurut Spencer yang dialih bahasakan oleh Kartini Dewi (2011 : 35) : “Kompetensi merupakan suatu karakteristik yang mendasar dari seseorang individu, yaitu penyebab yang terkait dengan efektivitas kerja" $A$ competency is an underlying characteristic of an 
individual that is causally related to criterion - referenced effective and/or superior performance in a job or situation"

Menurut Byars dan Rue yang diterjemahkan oleh Sri Mulyati (2008:46) kompetensi didefinisikan sebagai suatu sifat atau karakteristik yang dibutuhkan oleh seorang pemegang jabatan agar dapat melaksanakan jabatan dengan baik.

Sedangkan menurut pendapat Palan (2007:5) ada dua istilah yang muncul dari dua aliran yang berbeda tentang konsep kesesuaian dalam pekerjaan. Istilah tersebut adalah "Competency" (kompetensi) yaitu deskripsi mengenai perilaku, dan "Competence" (kecakapan) yang merupakan deskripsi tugas atau hasil pekerjaan.

\section{KERANGKA KONSEPTUAL DAN PENGEMBANGAN HIPOTESIS}

\subsection{Kerangka Konsep}

Sehubungan dengan permasalahan yang telah dirumuskan, dalam penelitian ini terdapat empat variabel yang akan diteliti. Empat variabel tersebut diklasifikasikan menjadi dua bagian, dapat dijelaskan sebagai berikut :

1. Variabel independen yakni : Struktur Organisasi (X1), Kepemimpinan (X2), Kompetensi Pegawai (X3)

2. Variabel dependen yakni : Efektivitas Pelayanan (Y)

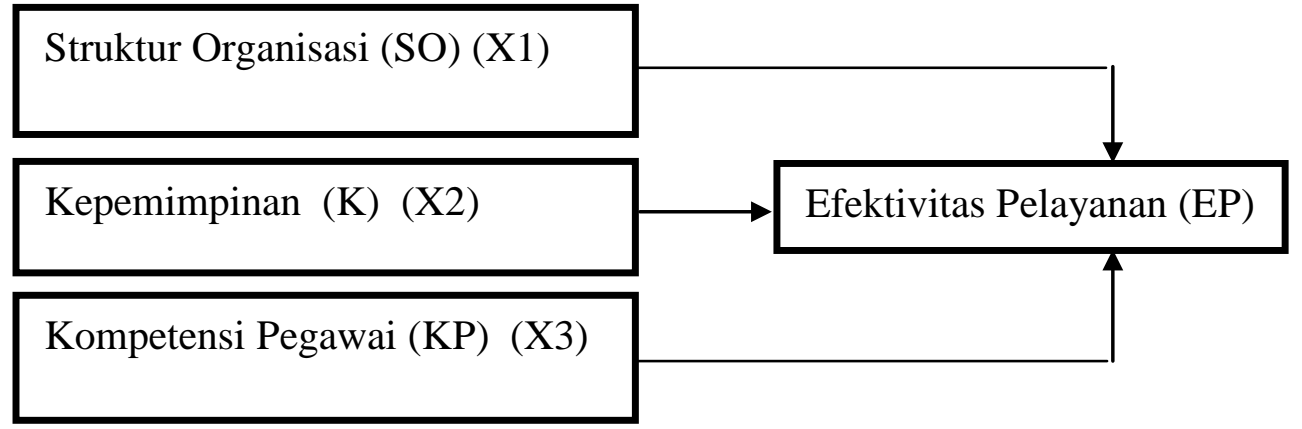

\subsection{Pengembangan Hipotesis}

\subsubsection{Pengaruh antara Struktur Organisasi dengan Efektivitas Layanan}

Menurut Siswanto (2005: 85) struktur organisasi menspesifikasikan pembagian kerja dan menunjukkan bagaimana fungsi atau aktivitas yang beraneka ragam yang dihubungkan sampai batas tertentu, juga menunjukkan tingkat spesialisasi aktivitas kerja.

Gibson dkk (1989 : 16 dan 17) bahwa struktur organisasi bukan hanya susunan porsi, tugas-tugas pekerjaan dan garis wewenang dari bagian-bagian dalam organisasi, tetapi merupakan pola formal kegiatan dan hubungan di antara berbagai subunit dalam organisasi. Struktur organisasi menjelaskan tentang pembagian tugas dan wewenang, tetapi struktur organisasi juga menjelaskan bagaimana pola hubungan kerja dari setiap unit yang ada. Sebuah struktur organisasi mempunyai tiga komponen dimensi : kompleksitas, formalisasi, dan sentralisasi (Robbins, $1994: 6$ ).

Jika struktur organisasi merupakan media yang membantu organisasi dalam mencapai tujuan-tujuannya, maka "efektivitas organisasi didefinisikan sebagai sejauh mana sebuah organisasi mewujudkan tujuan-tujuannya" (Robbins, 1994 : 53).

\subsubsection{Pengaruh antara Kepemimpinan dengan Efektivitas Layanan}

Robbins (2003 : 40) menyatakan bahwa kepemimpinan (leadership) adalah kemampuan untuk mempengaruhi suatu kelompok kearah tercapainya tujuan. Sementara Stoner (1996 : 161) menyatakan bahwa kepemimpinan adalah proses mengarahkan dan mempengaruhi aktifitas yang berkaitan dengan pekerjaan dari anggota kelompok. 
Kepemimpinan adalah sebagai suatu proses untuk mengarahkan dan mempengaruhi aktivitas-aktivitas anggota kelompok dan memberikan petunjuk, rasa gembira, kegairahan, kepercayaan semagat serta konsistensi kepada para anggota organisasi. Kurangnya peranan kepemimpinan dalam sebuah organisasi mengakibatkan kurang optimalnya kerja yang diselesaikan oleh para bawahannya baik menyangkut waktu dan hasil yang dicapainya. Hal ini sesuai dengan pendapat yang dikemukakan Hasibuan (2011) bahwa efektivitas bawahan sebagian besar ditentukan oleh efektivitas kepemimpinan seorang pemimpin. Salah satu contoh bawahan kurang terarah dalam mengerjakan tugas dan hal tersebut mengakibatkan efektivitas kerja menjadi terhambat.

\subsubsection{Pengaruh antara Kompetensi Pegawai dengan Efektivitas Layanan}

Kompetensi menurut Wibowo (2010: 324) adalah suatu kemampuan untuk melaksanakan atau melakukan suatu perkerjaan atau tugas yang dilandasi atas keterampilan dan pengetahuan serta didukung oleh sikap kerja yang dituntut oleh pekerjaan tersebut. Dengan demikian, kompetensi menunjukkan keterampilan atau pengetahuan yang dicirikan oleh profesionalisme dalam suatu bidang tertentu sebagai sesuatu yang terpenting, sebagai unggulan bidang tersebut.Menurut Spencer yang dialih bahasakan oleh Kartini Dewi (2011 : 35) : "Kompetensi merupakan suatu karakteristik yang mendasar dari seseorang individu, yaitu penyebab yang terkait dengan efektivitas kerja"

\section{METODE PENELITIAN}

\subsection{Jenis Penelitian, Populasi dan Sampel}

Jenis penelitian yang digunakan dalam penelitian ini adalah penelitian causal. Populasi dari penelitian ini adalah Pegawai Kantor Pertanahan Kota Mataram yang berhubungan langsung dengan pelayanan One Day Service yang berjumlah 50 orang. Berdasarkan penelitian ini karena jumlah populasinya tidak lebih besar dari 100 orang responden, maka penulis mengambil $100 \%$ jumlah populasi yang ada pada Kantor Pertanahan Kota Mataram yaitu sebanyak 50 orang responden.

\subsection{Variabel Penelitian dan Definisi Operasional Variabel}

\subsubsection{Struktur Organisasi}

Struktur Organisasi adalah tanggapan responden atas suatu jalur hirarki, pembagian wewenang yang menggambarkan tipe organisasi, pendepartemenan organisasi kedudukan dan jenis wewenang pejabat, bidang dan hubungan pekerjaan, garis perintah dan tanggung jawab, rentang kendali dan sistem pimpinan organisasi. Struktur menentukan seberapa luas organisasi mencerminkan dimensi kompleksitas, formalisasi, dan sentralisasi.

\subsubsection{Kepemimpinan}

Kepemimpinan merupakan persepsi responden terhadap perilaku pimpinan/atasan langsung dalam proses suatu keadaan yang menunjukkan pengetahuan, motivasi, kemampuan dan kemauan dari seseorang pimpinan untuk melaksanakan dan memimpin pegawainya agar mencapai suatu tujuan.

\subsubsection{Kompetensi Pegawai}

Kompetensi adalah tanggapan responden atas kemampuan yang dimiliki untuk melaksanakan atau melakukan suatu pekerjaan atau tugas yang dilandasi atas keterampilan dan pengetahuan serta didukung oleh sikap kerja yang dituntut oleh pekerjaan tersebut.

\subsubsection{Efektivitas Pelayanan}

Efektivitas pelayanan adalah tanggapan responden atas tercapainya suatu tujuan yang dilakukan oleh pemberi layanan dalam hal ini pegawai Kantor Pertanahan Kota Mataram yang berhubungan langsung dengan layanan One Day Service sesuai dengan 
ketentuan yang telah ditetapkan. Indikator efektivitas pelayanan yaitu : prosedur pelayanan, waktu penyelesaian, biaya pelayanan, produk pelayanan, sarana dan prasarana.

\section{HASIL PENELITIAN}

\subsection{Karakteristik Responden Penelitian}

Data karakteristik responden penelitian yang didapatkan meliputi jenis kelamin, pendidikan terakhir responden dan lama bekerja. Analisis deskriptif terhadap karakteristik responden didapatkan hasil bahwa, sebagian besar responden penelitian ini berjenis kelamin perempuan yaitu 33 orang $(66 \%)$. Pendidikan terakhir, sebagian besar responden penelitian ini telah menyelesaikan pendidikan SI/DIV yaitu 26 orang (52\%). Terkait lama bekerja, responden penelitian ini sebagian besar telah bekerja kurang dari 10 tahun yaitu 25 orang (50\%).

\subsection{Hasil Analisis Deskriptif Variabel Penelitian}

6.2.1. Variabel Struktur Organisasi

Hasil penelitian menunjukkan bahwa responden pegawai Kantor Pertanahan Kota Mataram memiliki pembagian tugas dan Struktur Organisasi yang tinggi. artinya pembagian tugas-tugas yang diberikan kepada pegawai Kantor Pertanahan Kota Mataram harus sesuai dengan kemampuan dan pengetahuan yang dimiliki. Tingkat ketepatan atau keberhasilan organisasi dapat dilihat dari kejelasan tujuan, mengatur aktivitas pegawainya dalam bentuk peraturan-peraturan, memanfaatkan teknologi serta didukung oleh kompetensi pegawainya.

\subsubsection{Variabel Kepemimpinan}

Hasil penelitian menunjukkan bahwa responden pegawai Kantor Pertanahan Kota Mataram memiliki pemimpin dengan tingkat sangat baik. Artinya setiap pemimpin harus memiliki wawasan dan pengetahuan yg luas sebagai modal untuk memimpin bawahannya. Kemampuan dan kesiapan yang dimiliki oleh pemimpin untuk dapat mempengaruhi, mendorong, mengajak, menuntun, menggerakan, dan mengarahkan pegawainya yang dapat membantu tercapainya suatu tujuan tertentu yang telah ditetapkan. Selain itu, pegawai Kantor Pertanahan Kota Mataram mengharapkan pimpinan yang bisa mengarahkan para bawahannya, karena kecakapan dan kewibawaan seorang pemimpin melaksanakan kepemimpinannya akan mendorong gairah kerja, kreativitas, partisipasi, dan loyalitas, para bawahannya untuk menyelesaikan tugas-tugasnya.

\subsubsection{Variabel Kompetensi Pegawai}

Hasil penelitian menunjukkan bahwa responden pegawai Kantor Pertanahan Kota Mataram memiliki kompetensi yang sangat tinggi. Artinya pegawai di Kantor Pertanahan Kota Mataram menginginkan setiap individu memiliki kemampuan dan pengetahuan dalam melaksanakan tugas-tugas yang diberikan pimpinan sehingga terlaksana sesuai dengan tujuan yang ditentukan.

\subsubsection{Efektivitas Pelayanan}

Hasil penelitian menunjukkan bahwa responden pegawai Kantor Pertanahan Kota Mataram memiliki efektivitas pelayanan One Day Service yang sangat efektif. Artinya pegawai di Kantor Pertanahan Kota Mataram menginginkan dalam melakukan pelayanan terhadap masyarakat harus sesuai dengan prosedur pelayanan, ketepatan waktu dalam menyelesaikan tugas, kesesuaian dalam biaya pelayanan, 
ketepatan dalam menyelesaikan produk pelayanannya dan tersedianya sarana dan prasarana yang baik.

\subsection{Hasil Uji Asumsi Klasik}

Uji Kolmogorov-Smirnov menunjukkan data berdistribusi normal, lulus uji multikolinieritas, lulus uji Autokorelasi dan lulus uji heteroskedastisitas sehingga hasil dari uji asumsi klasik layak untuk menggunakan analisa regresi linier berganda.

\subsection{Analisis Regresi Linier Berganda}

\subsubsection{Uji Signifikansi secara Simultan(Uji F)}

Berdasarkan hasil analisis diperoleh nilai-p untuk model regresi sebesar 0.000 yang lebih kecil dari nilai a (0.10), sehingga diputuskan untuk menolak $\mathrm{H}_{0}$. Dengan demikian dapat disimpulkan bahwa dengan tingkat kesalahan $5 \%$, terdapat pengaruh secara simultan variabel struktur organisasi, kepemimpinan, dan kompetensi pegawai berpengaruh terhadap efektivitas pelayanan.

\subsubsection{Uji Signifikansi secara Parsial (Uji T)}

\section{Hasil Pengujian Hipotesis 1}

Hipotesis pertama dalam penelitian ini menyatakan " diduga variabel struktur organisasi berpengaruh terhadap efektivitas pelayanan". Pembuktian hipotesis ini dilakukan dengan analisis uji $\mathrm{t}$ yang menunjukkan bahwa p-value < alfa 0,05 yang membuktikan bahwa struktur organisasi berpengaruh positif sebesar 0,427 terhadap efektivitas pelayanan. Artinya adalah pembagian kerja pegawai dalam struktur organisasi sudah sesuai dengan kompetensi yang dimiliki oleh masing-masing pegawai.

\section{Hasil Pengujian Hipotesis II}

Hipotesis kedua dalam penelitian ini menyatakan " diduga variabel kepemimpinan berpengaruh terhadap efektivitas pelayanan". Pembuktian hipotesis ini dilakukan dengan analisis uji $\mathrm{t}$ yang menunjukkan bahwa p-value > alfa 0,05 yang membuktikan bahwa kepemimpinan tidak berpengaruh secara siginifikan terhadap efektivitas pelayanan. Artinya bahwa seorang pimpinan tidak harus rutin melakukan kontrol terhadap pelaksanaan One Day Service, namun dari awal seorang pemimpin harus matang dalam merencanakan pembagian tugas-tugas yang akan diberikan kepada bawahannya sehingga sistem yang digunakan berjalan dengan baik.

\section{Hasil Pengujian Hipotesis III}

Hipotesis ketiga dalam penelitian ini menyatakan " diduga variabel kompetensi berpengaruh terhadap efektivitas pelayanan". Pembuktian hipotesis ini dilakukan dengan analisis uji $\mathrm{t}$ yang menunjukkan bahwa p-value < alfa 0,05 yang membuktikan bahwa kompetesi pegawai berpengaruh positif sebesar 0, 277 terhadap efektivitas pelayanan. Hal ini dapat diartikan jika pegawai memiliki kemampuan dan pengetahuan dalam melaksanakan tugasnya, maka efektivitas pelayanan One Day Service akan berjalan dengan baik. Begitupun sebaliknya jika pegawai tidak memiliki kemampuan dan pengetahuan maka efektivitas pelayanan One Day Service akan mengalami kendala.

Berdasarkan standar coeffesien beta untuk variabel strktur organisasi sebesar 0,479, kepemimpinan sebesar 0,092 dan variabel kompetensi pegawai sebesar 0,279. Hal ini menunjukkan bahwa variabel struktur organisasi memiliki pengaruh yang lebih dominan dari pada variabel kepemimpinan dan kompetensi pegawai terhadap efektivitas pelayanan. 
Tabel

\begin{tabular}{|c|c|c|c|c|c|c|c|c|c|c|}
\hline \multirow[b]{2}{*}{ Model } & \multicolumn{2}{|c|}{$\begin{array}{c}\text { Unstandardized } \\
\text { Coefficients }\end{array}$} & \multirow{2}{*}{$\begin{array}{c}\text { Standardized } \\
\text { Coefficients } \\
\text { Beta }\end{array}$} & \multirow[b]{2}{*}{$t$} & \multirow[b]{2}{*}{ Sig. } & \multicolumn{2}{|c|}{ Collinearity Statistics } & \multirow{2}{*}{$\mathrm{R}$} & \multirow{2}{*}{$\mathrm{R} 2$} & \multirow{2}{*}{$\begin{array}{l}\text { Adjust } \\
\mathrm{R} \\
\text { Square }\end{array}$} \\
\hline & B & $\begin{array}{l}\text { Std. } \\
\text { Error }\end{array}$ & & & & Tolerance & VIF & & & \\
\hline 1 (Constan) & 1.198 & .485 & & 2.470 & .017 & & & 717 & 514 & 482 \\
\hline $\mathrm{X} 1$ & .427 & .125 & .479 & 3.402 & .001 & .533 & 1,877 & & & \\
\hline $\mathrm{X} 2$ & .071 & .103 & .092 & .689 & .494 & .594 & 1,685 & & & \\
\hline X3 & .277 & .116 & .279 & 2.398 & .021 & .780 & 1,282 & & & \\
\hline
\end{tabular}

Sumber : Data Primer Diolah, 2019

\subsection{Uji Koefesien Determinasi (R2)}

Berdasarkan hasil penelitian nilai R Square $\left(\mathrm{R}^{2}\right)$ sebesar 0,482 (48,2 \%) artinya variabel Struktur organisasi, kepemimpinan, dan kompetensi pegawai hanya memberikan pengaruh sebesar $48,2 \%$ terhadap efektivitas pelayanan. Sedangkan 51,8 \% efektivitas pelayanan dari individu dipengaruhi oleh faktor lain yang tidak dijelaskan dalam model.

\section{PEMBAHASAN}

\subsection{Pengaruh Struktur Organisasi terhadap Efektivitas Pelayanan}

Struktur organisasi mengindikasikan alur perintah yang mengindikasi jabatan pekerjaan yang harus dipertanggung jawabkan oleh masing-masing tipe pegawai. Struktur organisasi berfungsi sebagai alat untuk membimbing kearah efisiensi dalam penggunaan pekerja dan seluruh sumber daya yang dibutuhkan dalam meraih tujuan organisasi

Adapun teori stuktur organisasi yang digunakan oleh penulis sebagai pisau analisis dalam permasalahan ini yaitu teori struktur Organisasi oleh Gibson dkk (1989:16 dan 17), bahwa struktur organisasi bukan hanya susunan porsi, tugas-tugas pekerjaan dan garis wewenang dari bagian-bagian dalam organisasi, tetapi merupakan pola formal kegiatan dan hubungan di antara berbagai subunit dalam organisasi. Struktur organisasi menjelaskan tentang pembagian tugas dan wewenang, tetapi struktur organisasi juga menjelaskan bagaimana pola hubungan kerja dari setiap unit yang ada.

Sulistio dan Budi (2009 : 29) berpendapat bahwa struktur adalah kerangka organisasi yang merupakan visualisasi dari tugas, fungsi, garis wewenang dan tanggung jawab, jabatan dan jumlah pejabat serta batas-batas formal dalam hal apa organisasi itu beroperasi. Struktur organisasi adalah gambaran bagi anggota maupun bagi masyarakat luar (bukan anggota) tentang keadaan organisasi, seperti tugasnya; fungsi; garis wewenang; jabatan; dan jumlah pejabat.

Handoko dalam Ambonowati (2002 : 23) menegaskan bahwa struktur organisasi dapat didefinisikan sebagai mekanisme-mekanisme formal dengan mana organisasi dikelola. Handoko juga menyebutkan bahwa struktur organisasi ini mengandung unsurunsur spesialisasi kerja, standarisasi, koordinasi, sentralisasi atau desentralisasi dalam pembuatan keputusan dan besaran (ukuran) satuan kerja.

Hasil analisis menunjukkan bahwa struktur organisasi berpengaruh positif dan signifikan terhadap efektivitas pelayanan program one day service. Artinya adalah pembagian kerja pegawai dalam struktur organisasi sudah sesuai dengan kompetensi yang dimiliki oleh masing-masing pegawai.

Dengan demikian hipotesis penelitian pengaruh variabel struktur organisasi terhadap efektivitas pelayanan dapat dibuktikan kebenarannya. Terbukti hipotesis ini sejalan dengan hasil penelitian yang dilakukan oleh Prasetyaningsih 2009, yang 
menyatakan bahwa Struktur organisasi berpengaruh positif dan signifikan terhadap efektivitas pelayanan. Kesimpulan ini juga sejalan dengan hasil penelitian yang dilakukan Hadian, yang bertujuan untuk menganalisis dan mengkaji pengaruh kepemimpinan, struktur organisasi dan budaya organisasi terhadap kinerja dinas dan pelayanan publik. Hasil penelitian menunjukkan bahwa struktur organisasi pada pelayanan program one day service di Kantor Pertanahan Kota Mataram berpengaruh positif terhadap pelayanan publik.

\subsection{Pengaruh Kepemimpinan terhadap Efektivitas Pelayanan}

Berdasarkan hasil penelitian membuktikan bahwa kepemimpinan berpengaruh positif tidak signifikan terhadap efektivitas pelayanan one day service artinya bahwa seorang pimpinan tidak harus rutin melakukan kontrol terhadap pelaksanaan One Day Service, namun dari awal seorang pemimpin harus matang dalam merencanakan pembagian tugastugas yang akan diberikan kepada bawahannya sehingga sistem yang digunakan berjalan dengan baik.

Hipotesis kedua ini dapat dibuktikan kebenarannya. Implikasinya bahwa Kantor Pertanahan Kota Mataram harus memiliki pemimpin yang mampu mengatur dan menggerakkan bawahannya serta berkontribusi dalam perkembangan sebuah organisasi, dengan demikian pemimpin tersebut sudah dianggap mampu dan mumpuni dalam melaksanakan kepemimpinannya secara efektif. Hasil ini menguatkan teori yang dinyatakan oleh Robbins (2003 : 40) menegaskan bahwa kepemimpinan (leadership) merupakan kemampuan untuk mempengaruhi suatu kelompok kearah tercapainya tujuan. Sementara Stoner (1996 : 161) menegaskan bahwa kepemimpinan adalah proses mengarahkan dan mempengaruhi aktifitas yang berkaitan dengan pekerjaan dari anggota kelompok.

Hasil penelitian ini sejalan dengan penelitian yang dilakukan oleh Rusmaini (2017) menunjukkan bahwa Kepemimpinan berpengaruh positif tidak signifikan terhadap efektivitas kerja artinya seorang pemimpin telah mampu menggerakkan organisasi dan membuat pegawai menjadi lebih baik dalam bekerja dengan mengacu kepada standar operasional prosedur.

Menurut Yukl dalam Idris, (2006 : 57) kepemimpinan merupakan proses pemimpin yang mempengaruhi pengikut untuk menginterpretasikan keadaan, pemilihan tujuan organisasi, pengorganisasian kerja dan memotivasi pengikut untuk mencapai tujuan organisasi, mempertahankan kerjasama dan tim kerja, mengorganisir dukungan dan kerja sama orang dari luar organisasi.

Dilihat dari tanggapan 50 responden terhadap item pernyataan pada variabel kepemimpinan secara umum dikategorikan sangat baik, artinya pegawai Kantor Pertanahan Kota Mataram menginginkan pemimpin yang memiliki kemampuan dalam bekerjasama dengan bawahannya, membantu mengarahkan dan memotivasi pegawai saat melakukan kegiatan. Dengan demikian, pengaruh kepemimpinan dalam hal ini kepala kantor Pertanahan Kota Mataram dan sub seksi yang berkaitan dengan pelayanan telah membawa pengaruh positif terhadap kelompok, pegawai terutama yang berhubungan langsung dalam program one day service. Pemimpin yang efektif dalam hubungan dengan bawahan adalah pemimpin yang mampu meyakinkan mereka bahwa kepentingan pribadi dari bawahan adalah visi pemimpin, serta mampu meyakinkan bahwa mereka mempunyai andil dalam mengimplementasikannya. 


\subsection{Pengaruh Kompetensi Pegawai terhadap Efektivitas Pelayanan}

Kompetensi menurut Wibowo (2010: 324) adalah suatu kemampuan untuk melaksanakan atau melakukan suatu perkerjaan atau tugas yang dilandasi atas keterampilan dan pengetahuan serta didukung oleh sikap kerja yang dituntut oleh pekerjaan tersebut. Dengan demikian, kompetensi menunjukkan keterampilan atau pengetahuan yang dicirikan oleh profesionalisme dalam suatu bidang tertentu sebagai sesuatu yang terpenting, sebagai unggulan bidang tersebut.

Menurut Spencer \& Spencer yang dialih bahasakan oleh Kartini Dewi (2011 : 35) : "Kompetensi merupakan suatu karakteristik yang mendasar dari seseorang individu, yaitu penyebab yang terkait dengan efektivitas kerja" A competency is an underlying characteristic of an individual that is causally related to criterion-referenced effective and/or superior performance in a job or situation" Menurut Byars dan Rue yang diterjemahkan oleh Sri Mulyati (2008 : 46) kompetensi didefinisikan sebagai suatu sifat atau karakteristik yang dibutuhkan oleh seorang pemegang jabatan agar dapat melaksanakan jabatan dengan baik.

Berdasarkan hasil penelitian kompetensi pegawai di Kantor Pertanahan Kota Mataram membuktikan bahwa kompetensi pegawai berpengaruh positif dan signifikan terhadap efektivitas pelayanan One Day Service. Hal ini dapat diartikan jika pegawai memiliki kemampuan dan pengetahuan dalam melaksanakan tugasnya, maka efektivitas pelayanan One Day Service akan berjalan dengan baik. Begitupun sebaliknya jika pegawai tidak memiliki kemampuan dan pengetahuan maka efektivitas pelayanan One Day Service akan mengalami kendala.

Dengan demikian maka hipotesis ketiga pada penelitian ini dapat dibuktikan kebenarannya. Implikasinya bahwa Kantor Pertanahan Kota Mataram harus menempatkan pegawai sesuai dengan kompetensi yang dimilikinya agar program pelayanan One Day Service berjalan dengan baik. Hasil ini menguatkan teori Kompetensi menurut Wibowo (2010 : 324). Penelitian yang dilakukan oleh Nasution dkk (2014) menunjukkan bahwa kompetensi pegawai berpengaruh positif dan signifikan terhadap efekivitas organisasi artinya rata-rata pegawai mempersepsikan mereka memiliki kompetensi yang cukup tinggi dalam melaksanakan tugas-tugas yang diberikan.

\section{KESIMPULAN}

1. Struktur organisasi berpengaruh positif dan signifikan terhadap efektivitas pelayanan, Hal ini menunjukkan bahwa dengan struktur organisasi yang jelas, dan penempatan pegawai yang sesuai dengan kompetensi pada struktur organisasi, akan meningkatkan efektivitas pelayanan One Day Service. Struktur organisasi yang terdiri dari pendelegasian/pembagian tugas pokok dan fungsi, kejelasan pelaksanaan tugas antar seksi, dan hubungan antara atasan dan bawahan, jika dilaksanakan dengan baik dan selalu ditingkatkan maka efektivitas pelayananakan meningkat.

2. Pengaruh kepemimpinan pada Kantor pertanahan kota Mataram dari hasil penelitian dan uji validitas bernilai positif, bermakna bahwa semakin tinggi skor kepemimpinan, maka efektivitas pelayanan dari masing-masing individu meningkat. Kepemimpinan dan pengkoordinasian secara interen dari kepala kantor Pertanahan Mataram hingga sub seksi yang bertanggung jawab penuh atas program one day service sangat memberikan dampak positif dan sangat efektif terhadap kinerja pelayanan publik di Kantor Pertanahan Kota Mataram.

3. Kompetensi pegawai berpengaruh positif dan signifikan terhadap efektivitas pelayanan program One day Service. Artinya jika pegawai memiliki kemampuan dan pengetahuan dalam melaksanakan tugasnya, maka efektivitas pelayanan One Day Service akan berjalan 
dengan baik. Begitupun sebaliknya jika pegawai tidak memiliki kemampuan dan pengetahuan maka efektivitas pelayanan One Day Service akan mengalami kendala.

\section{SARAN}

Adapun saran (rekomendasi) yang dapat diberikan sehubungan denganefektivitas pelayanan program One Day Service pada Kantor Pertanahan Kota Mataram, adalah sebagai berikut :

1. Hendaknya program One Day Service di jadikan acuan sebagai program yang memberikan pelayanan terhadap masyarakat memiliki tim khusus demi memberikan kenyamanan bagi masyarakat dalam mengurus dokumen terkait dengan pemberkasan pertanahan.

2. Hendaknya pemerintah lebih mengoptimalkan lagi dalam memberikan pelayanan pada masyarakat terkait dengan pemberkasan pertanahan seperti menyediakan fasilitas dan sarana dan prasana, program-program one day service demi tercapainya visi-misi kantor badan pertanahan kota Mataram Khususnya, dan umumnya BPN RI.

3. Diharapkan pada Peneliti selanjutnya untuk lebih memfokuskan pada Variabel Individu yang dapat mengakibatkan dan mempengaruhi efektifitas pelayanan publik pada program one day service, sebab pada penelitian ini terdapat $51,8 \%$ efektivitas pelayanan dari individu dipengaruhi oleh faktor lain yang tidak dijelaskan dalam model pada Kantor Badan Pertanahan Kota Mataram.

\section{DAFTAR PUSTAKA}

Ambonowati, Lely.2002. Analisis Struktur Organisasi terhadap Efektivitas Organisasi Badan Kesatuan Bangsa dan Perlindungan Masyarakat Propinsi Jawa Tengah. Semarang : Universitas Diponegoro.

Bejo, Siswanto. 2005. Manajemen Tenaga Kerja Indonesia Pendekatan Administrarif dan Operasional. Jakarta : Bumi Aksara.

Byars, Llloyd L dan Rue, Leslie W., (2008). Human Resource Management, 8 edition. MCGraw-Hill

Creswell, J.,W. 2013. Research Design : Qualitative, Quantitative and Mix Methods Approaches. $4^{\text {th }}$ edition. California : Sage Publication

Fahmi, Irham ,2012. Manajemen Kepemimpinan : Teori \& Aplikasi. Cetakan Kesatu. Bandung : Alfabeta.

Fandy Tjiptono. 1995. Strategi Pemasaran. Yogyakarta : Andi Offset.

Gibson, James L; dkk 1994. Organisasi dan Manajemen. Edisi 4. Jakarta. Erlangga

Gibson, James L.; dkk. 1989. Organisasi (jilid 1). Jakarta : Erlangga

Hasibuan, S.P.M. 2011. Manajemen Dasar, Pengertian, dan Masalah. CV. Haji Masagung, Jakarta.

Idris. 2006. Pengaruh Gaya Kepemimpinan, Budaya Perusahaan, dan Pengemba-ngan Sumberdaya Manusia Terhadap Kinerja Karyawan Industri Kakao pada Kawasan Industri Makassar di Sulawesi Selatan. Tesis. Tidak diterbitkan. Palu : Program Pascasarjana Universitas Tadulako.

Ivancevich, Jhon M. Et al. 2007 .Perilaku dan Manajemen Organisasi. Jakarta : Erlangga Moenir, H.A.S. 2001. Manajemen Pelayanan Umum di Indonesia. Jakarta: Bumi Aksara. 
Nasution, Ningsih dan Fitri. 2014. Pengaruh Kepemimpinan Dan Kompetensi Terhadap Efektivitas Organisasi Pada Pegawai Negeri Sipil Di Lingkungan Badan Kepegawaian Negara Kantor Regional XII. JOM Fekon Vol. 1 No. 2 Oktober 2014

Palan, R (2007). Competency and magement. Teknis Mengimplementasikan Manajemen SDM Berbasis Kompetensi Untuk Meningkatkan Daya saing Organisasi. PPM. Jakarta

Pasolong, Harbani. 2008. Kepemimpinan Birokrasi. Bandung: Alfabeta.

Prasetyaningsih.2009, Pengaruh struktur organisasi, kepemimpinan dan Kemampuan sdm terhadap efektivitas pelayanan Pensertifikatan hak atas tanah Pada kantor pertanahan kabupaten kendal.

Ratminto. 2005. Manajemen Pelayanan, disertai dengan pengembangan model konseptual, penerapan citizen's charter dan standar pelayanan minimal. Yogyakarta : Pustaka Pelajar

Robbin, Stephen P.; alih bahasa : Jusuf Udaya. 1994. Teori Organisasi : Struktur, Desain dan Aplikasi. Jakarta : Arcan

Robbins, Stephen P. 2003. Perilaku Organisasi. Jakarta : Indeks

Rusmaini, 2017 Penelitian ini berjudul : Pengaruh Kepemimpinan Terhadap Efektivitas Kerja Pegawai di Fakultas Ilmu Tarbiyah dan Keguruan UIN Raden Fatah Palembang. Journal of Islamic Education Management, Desember 2017, Vol. 3 No. 2,

Siagian Sondang P., 2002. Kiat Meningkatkan Produktivitas Kerja, Cetakan Pertama, PT. Rineka Cipta, Jakarta.

Slater, Robert (2001). Jack Welch and The GE Way : Wawasan Manajemen dan Rahasia Kepemimpinan CEO Legendaris (Terjemah oleh Fandy Tjiptono). Edisi I. Yogyakarta : Andi.

Spencer, Lyle, M.Jr. dan Signe M. Spencer., (2011), Competence at Work. New York : John Wiley \& Sons, Inc

Steers, M Richard. (1985). Efektivitas Organisasi Perusahaan. Jakarta : Erlangga.

Stoner, James A.F., R. Edward Freeman, dan Daniel R. Gilbert Jr. (1996), Manajemen, Jilid II, Jakarta : Prenhallindo.

Sulistio, Eko dan Budi, Waspa Kusuma. 2009. Birokrasi Poblik : Perspektif Ilmu Administrasi Publik. Metro : STISIPOL Dharma Wacana Metro

Sutrisno Edy, 2010. Budaya Organisasi. Kencana Prenada Media Group. Jakarta.

Tika H. Moh. Pabundu, 2006. Budaya Organisasi dan Peningkatan Kinerja Perusahaan, Cetakan Pertama, PT. Bhumi Aksara, Jakarta.

Wibowo. (2010). Manajemen Kinerja. Jakarta : Rajawali Press.

Wibowo.2013, Manajemen Kinerja, Edisi Ketiga, Jakarta : PT Raja Grafindo Persada 